Pacific Journal of Mathematic 


\title{
A SUBCOLLECTION OF ALGEBRAS IN A COLLECTION OF BANACH SPACES
}

\author{
ROBERT PAUL KOPP
}

Let $D(p, r)$ with $1 \leqq p<\infty$ and $-\infty<r<+\infty$ denote the Banach space consisting of certain analytic functions $f(z)$ defined in the unit disk. A function $f(z)=\sum_{n=0}^{\infty} a_{n} z^{n}$ is a member of $D(p, r)$ if and only if

$$
\sum_{n=0}^{\infty}(n+1)^{r}\left|a_{n}\right|^{p}<\infty .
$$

We define the norm of $f$ in $D(p, r)$ by

$$
\|f\|_{p, r}=\left(\sum_{n=0}^{\infty}(n+1)^{r}\left|a_{n}\right|^{p}\right) 1 / p .
$$

By the product of two functions $f$ and $g$ in $D(p, r)$ we shall mean their product as functions, i.e., $[f . g](z)=f(z) g(z)$. The purpose of this paper is to discover which of the spaces $D(p, r)$ are algebras.

THEOREM 1. If $D(p, r)$ is an algebra, then there exists a real $c>0$ with $\|f g\| \leqq c\|f\|\|g\|$ for every $f, g \in D(p, r)$.

Proof. Let $h$ be a fixed element of $D(p, r)$. It suffices to show the map $f \rightarrow h f$ is a bounded linear transformation from $D(p, r)$ to itself. The proof is based on the closed graph theorem [2, p. 306]. Suppose $h$ is a multiplier from $D\left(p_{1}, r_{1}\right)$ to $D\left(p_{2}, r_{2}\right)$ and suppose

(i) $f_{n} \rightarrow f$ in $D\left(p_{1}, r_{1}\right)$ and

(ii) $h f_{n} \rightarrow g$ in $D\left(p_{2}, r_{2}\right)$.

Then $f_{n}(z) \rightarrow f(z)$ for each $z$ in the unit disk and so $h(z) f_{n}(z) \rightarrow h(z) f(z)$. On the other hand by (ii), $h(z) f_{n}(z) \rightarrow g(z)$ for each $z$ in the unit disk. Hence $g=h f$, and so by the closed graph theorem multiplication by $h$ is a continuous linear transformation. It follows from this [2, p. 183] that $D(p, r)$ is equivalent to a Banach algebra, and from this the theorem follows immediately.

Corollary 1. If $D(p, r)$ is an algebra and $c>0$ as above, then $|f(z)| \leqq c\|f\| \forall f \in D(p, r)$ and $|z|<1$.

Proof. For each $f$ in $D(p, r)$ let $T_{f}$ denote the multiplication operator from $D(p, r)$ to itself determined by $f$, i.e., $T_{f}(g)=f g$. Then for $z_{0}$ satisfying $\left|z_{0}\right|<1$ the map $T_{f} \rightarrow f\left(z_{0}\right)$ is a multiplicative linear functional on the Banach algebra of multiplication operators

$$
T_{f}, f \in D(p, r)
$$


with the usual norm. Hence

$$
\left|f\left(z_{0}\right)\right| \leqq\left\|T_{f}\right\|=\sup _{\|g\|=1}\|f g\| \leqq c\|f\|, g \in D(p, r) .
$$

Theorem 2. If $p=1$, then $D(p, r)$ is no algebra for $r<0$. And if $1<p<\infty$, then $D(p, r)$ is no algebra for $r \leqq p-1$.

Proof. The function $f(z)=\sum_{n=0}^{\infty}[1 /(n+1)] z^{n}$ is an unbounded function on $|z|<1$ but lies in $D(1, r)$ if $r \leqq 0$. And similarly the function $f(z)=\sum_{n=0}^{\infty} 1 /[(n+1) \log (n+1)] z^{n}$ is an unbounded function on $|z|<1$ in $D(p, r)$ if $p>1$ and $r \leqq p-1$. Therefore by Corollary 1 the spaces are not algebras.

THEOREM 3. If $p=1$, then $D(p, r)$ is an algebra for $r \geqq 0$, and if $1<p<\infty$ then $D(p, r)$ is an algebra for $r>p-1$.

Proof. (i ) Suppose first $f(z)=\sum_{n=0}^{\infty} a_{n} z^{n}$ and $g(z)=\sum_{n=0}^{\infty} b_{n} z^{n}$ lie in $D(1, r)$ with $r \geqq 0$. We will show $f g \in D(1, r)$

$$
\begin{aligned}
\|f g\| & =\sum_{n=0}^{\infty}(n+1)^{r}\left|\sum_{k=0}^{n} a_{k} b_{n-k}\right| \leqq \sum_{n=0}^{\infty}(n+1)^{r} \sum_{k=0}^{n}\left|a_{k}\right|\left|b_{n-k}\right| \\
& =\sum_{k=0}^{\infty} \sum_{n=k}^{\infty}(n+1)^{r}\left|a_{k}\right|\left|b_{n-k}\right| \\
& =\sum_{k=0}^{\infty} \sum_{j=0}^{\infty}(j+k+1)^{r}\left|a_{k}\right|\left|b_{j}\right| \text { where } j=n-k \\
& =\sum_{k=0}^{\infty} \sum_{j=0}^{\infty}(j+k+1)^{r} /\left[(k+1)^{r}(j+1)^{r}\right](k+1)^{r}\left|a_{k}\right|(j+1)^{r}\left|b_{j}\right| \\
& =\sum_{k=0}^{\infty} \sum_{j=0}^{\infty}[(j+k+1) /(j k+j+k+1)]^{r}(k+1)^{r}\left|a_{k}\right|(j+1)^{r}\left|b_{j}\right| \\
& \leqq \sum_{k=0}^{\infty} \sum_{j=0}^{\infty}(k+1)^{r}\left|a_{k}\right|(j+1)^{r}\left|b_{j}\right| \\
& =\|f\|\|g\| .
\end{aligned}
$$

(ii) Now suppose $r>p-1$, and let

$$
f(z)=\sum_{n=0}^{\infty} a_{n} z^{n} \quad \text { and } \quad g(z)=\sum_{n=0}^{\infty} b_{n} z^{n}
$$

be two elements of $D(p, r)$. We will show there is a constant $K$ such that $\|f g\| \leqq K\|f\|\|g\|$. Define $q$ by the equation $1 / p+1 / q=1$.

$$
\begin{aligned}
\|f g\|^{p} & =\sum_{n=0}^{\infty}(n+1)^{r}\left|\sum_{k=0}^{n} a_{k} b_{n-k}\right|^{p} \leqq \sum_{n=0}^{\infty}(n+1)^{r} \\
& \left\{\sum_{k=0}^{n} 1 /\left[(k+1)^{r / p}(n-k+1)^{r / p}\right](k+1)^{r / p}\left|a_{k}\right|(n-k+1)^{r / p}\left|b_{n-k}\right|\right\}^{p} \cdot
\end{aligned}
$$

Applying Holder's inequality we get 


$$
\begin{aligned}
& \|f g\|^{p} \\
& \leqq \sum_{n=0}^{\infty}(n+1)^{r}\left\{\left(\sum_{k=0}^{n}\left[1 /\left\{(k+1)^{r / p}(n-k+1)^{r / p}\right\}\right]^{q}\right)^{1 / q}\right. \\
& \left.\qquad\left(\sum_{k=0}^{n}(k+1)^{r}\left|a_{k}\right|^{p}(n-k+1)^{r}\left|b_{n-k}\right|^{p}\right)^{1 / p}\right\}^{p} \\
& =\sum_{n=0}^{\infty}\left[C_{n}\right] \sum_{k=0}^{n}(k+1)^{r}\left|a_{k}\right|^{p}(n-k+1)^{r}\left|b_{n-k}\right|^{p} \\
& \leqq \sup _{n}\left[C_{n}\right]\|f\|^{p}\|g\|^{p}
\end{aligned}
$$

where

$$
\left.C_{n}=(n+1)^{r}\left(\sum_{k=0}^{n}\left\{1 /[k+1)^{r / p}(n-k+1)^{r / p}\right]\right\}^{q}\right)^{p / q} .
$$

We complete the proof of the theorem by showing

$$
\begin{aligned}
& \sup _{n}\left[C_{n}\right]<\infty . \\
& C_{n}=(n+1)^{r}\left(\sum_{k=0}^{n}\left\{1 /\left[(k+1)^{r / p}(n-k+1)^{r / p}\right]\right\}^{q}\right)^{p / q} \\
& =(n+1)^{r}\left(\sum_{k=0}^{n} 1 /(n+2)^{r q / p}\{1 /(k+1)+1 /(n-k+1)\}^{r q / p}\right)^{p / q} \\
& =[(n+1) /(n+2)]^{r}\left[\sum_{k=0}^{n}\{1 /(k+1)+1 /(n-k+1)\}^{r q / p}\right]_{p / q} \\
& \leqq\left[\sum_{k=0}^{n}\{2 /(k+1)\}^{r q / p}\right]_{p / q} \\
& \leqq 2^{r}\left[\sum_{k=0}^{\infty} 1 /(k+1)^{r q / p}\right]_{p / q}
\end{aligned}
$$

since

$$
r q / p=r /(p-1)>1
$$

I should like to thank Professors Allen L. Shields and Gerald Taylor for some of the ideas in this paper. In addition, I should like to thank the referee for considerably simplifying the paper.

\section{BIBLIOGRAPHY}

1. A. M. Naimark, Normed rings, P. Noordhoff N. V., Gronigen Netherlands, 1964.

2. F. Riesz, and Bela S. Z. Nagy, Functional analysis, Ungar Publishing Company, New York.

Received February 26, 1968.

San Diego State College 



\title{
PACIFIC JOURNAL OF MATHEMATICS
}

\author{
EDITORS
}

H. ROYDEN

Stanford University

Stanford, California

R. R. PhelPS

University of Washington

Seattle, Washington 98105
J. DUGUNDJI

Department of Mathematics

University of Southern California

Los Angeles, California 90007

RICHARD ARENS

University of California

Los Angeles, California 90024

\section{ASSOCIATE EDITORS}
E. F. BECKENBACH
B. H. NeumanN
F. WOLF
K. YoSHIDA

\section{SUPPORTING INSTITUTIONS}

\author{
UNIVERSITY OF BRITISH COLUMBIA \\ CALIFORNIA INSTITUTE OF TECHNOLOGY \\ UNIVERSITY OF CALIFORNIA \\ MONTANA STATE UNIVERSITY \\ UNIVERSITY OF NEVADA \\ NEW MEXICO STATE UNIVERSITY \\ OREGON STATE UNIVERSITY \\ UNIVERSITY OF OREGON \\ OSAKA UNIVERSITY \\ UNIVERSITY OF SOUTHERN CALIFORNIA
}

\author{
STANFORD UNIVERSITY \\ UNIVERSITY OF TOKYO \\ UNIVERSITY OF UTAH \\ WASHINGTON STATE UNIVERSITY \\ UNIVERSITY OF WASHINGTON \\ $\stackrel{*}{*} \stackrel{*}{*}{ }^{*}{ }^{*}$ \\ CHEVRON RESEARCH CORPORATION \\ TRW SYSTEMS \\ NAVAL WEAPONS CENTER
}

The Supporting Institutions listed above contribute to the cost of publication of this Journal, but they are not owners or publishers and have no responsibility for its content or policies.

Mathematical papers intended for publication in the Pacific Journal of Mathematics should be in typed form or offset-reproduced, double spaced with large margins. Underline Greek letters in red, German in green, and script in blue. The first paragraph or two must be capable of being used separately as a synopsis of the entire paper. It should not contain references to the bibliography. Manuscripts, in duplicate if possible, may be sent to any one of the four editors. Please classify according to the scheme of Math. Rev. 36, 1539-1546. All other communications to the editors should be addressed to the managing editor, Richard Arens, University of California, Los Angeles, California, 90024.

50 reprints are provided free for each article; additional copies may be obtained at cost in multiples of 50 .

The Pacific Journal of Mathematics is published monthly. Effective with Volume 16 the price per volume (3 numbers) is $\$ 8.00$; single issues, $\$ 3.00$. Special price for current issues to individual faculty members of supporting institutions and to individual members of the American Mathematical Society: $\$ 4.00$ per volume; single issues $\$ 1.50$. Back numbers are available.

Subscriptions, orders for back numbers, and changes of address should be sent to Pacific Journal of Mathematics, 103 Highland Boulevard, Berkeley, California, 94708.

PUBLISHED BY PACIFIC JOURNAL OF MATHEMATICS, A NON-PROFIT CORPORATION

Printed at Kokusai Bunken Insatsusha (International Academic Printing Co., Ltd.), 7-17, Fujimi 2-chome, Chiyoda-ku, Tokyo, Japan. 


\section{Pacific Journal of Mathematics \\ Vol. 30, No. $2 \quad$ October, 1969}

Gregory Frank Bachelis, Homomorphisms of annihilator Banach algebras.

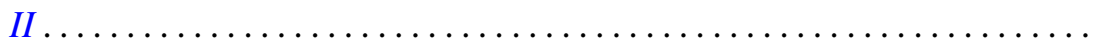

Leon Bernstein and Helmut Hasse, An explicit formula for the units of an algebraic number field of degree $n \geq 2 \ldots \ldots \ldots \ldots \ldots \ldots \ldots . \ldots 29$

David W. Boyd, Best constants in a class of integral inequalities ........ 367

Paul F. Conrad and John Dauns, An embedding theorem for lattice-ordered

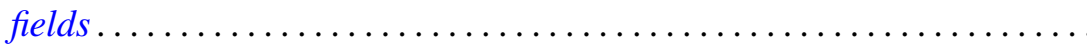

H. P. Dikshit, Summability of Fourier series by triangular matrix

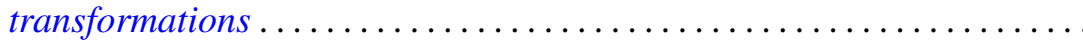

Dragomir Z. Djokovic, Linear transformations of tensor products preserving a fixed rank............................. 411

John J. F. Fournier, Extensions of a Fourier multiplier theorem of Paley . . . 415 Robert Paul Kopp, A subcollection of algebras in a collection of Banach

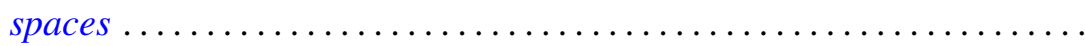

Lawrence Louis Larmore, Twisted cohomology and enumeration of vector bundles ...................................... 437

William Grenfell Leavitt and Yu-Lee Lee, A radical coinciding with the lower radical in associative and alternative rings .................

Samuel Merrill and Nand Lal, Characterization of certain invariant subspaces of $H^{p}$ and $L^{p}$ spaces derived from logmodular

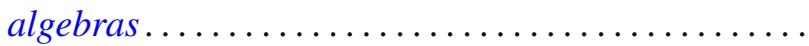

Sam Bernard Nadler, Jr., Multi-valued contraction mappings ....

T. V. Panchapagesan, Semi-groups of scalar type operators in Banach spaces ....................................

J. W. Spellmann, Concerning the infinite differentiability of semigroup motions

H. M. (Hari Mohan) Srivastava, A note on certain dual series equations involving Laguerre polynomials.

Ernest Lester Stitzinger, A nonimbedding theorem of associative algebras................................

J. Jerry Uhl, Jr., Martingales of vector valued set functions ...

John Mays Worrell Jr., On continuous mappings of metacompact $\check{C} e c h$

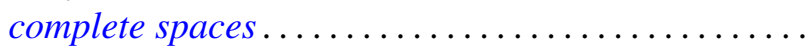

